\title{
Error Analysis of Newman to Solve the Geometry Problem in Terms of Cognitive Style
}

\author{
Kenys Fadhilah Zamzam ${ }^{1}$, Firda Alfiana Patricia ${ }^{2}$ \\ Mathematics education \\ IKIP Budi Utomo Malang \\ INDONESIA \\ ${ }^{1}$ kenysfz@gmail.com \\ ${ }^{2}$ firdaalfianapatricia@yahoo.com
}

\begin{abstract}
Abstrak. Problem solving plays an important role in mathematics education because it could train students with mathematically minded. Many mistakes are still encountered in solving mathematical problems, especially on the matter of geometry. In this study has a purpose to describe student error in problem solving using Newman analysis (NEA) to solve the problem of geometry in terms of cognitive style. Newman analysis is a method of student error analysis in solving problems in the form of a description problem. This research is included in qualitative research with the subjects of this study are 4 students of class of 2016 mathematics education course IKIP Budi Utomo Malang, each consisting of students with different cognitive and gender styles. Data collection techniques in this study using test and interview techniques. Instrument for knowing reflexive cognitive style and impulsive cognitive style using MFFT (matching familiar figure test) to categorize students (fastaccurate, impulsive, reflexive, slow-inaccurate).

Data analysis in this research use Miles and

Huberman model. The result of the research shows that frequently mistake is in the transformation stage and skill process, it caused the students not to understand the procedure that will be used to solve the problem of the material is not well understood. In addition, the students showed a cognitive style that was more likely to be cognitive impulsive and reflexive style of $67.5 \%$.
\end{abstract}

Keyword-Cognitive style; problem solving; Newman analysis

\section{NTRODUCTION}

Problem solving plays an important role in mathematics education because it could train students to think mathematically. This problem solving also designed students to create new ideas, discover new techniques or products. Not of all in mathematics could be categorized in problem solving even though mathematic is the form of a description problem whose solution requires mathematical calculation. If the questions given to students and students immediately know how to solve it then the problem is not a problem-solving category. In this case, a problem can be categorized in problem solving if the given problem is not a problem that is often studied by students and problems that have been known to answer from courses that have been obtained by students.

Stages of problem solving: 1 . understand the problem; 2. Plan the solution; 3 . resolving the problem as planned; 4. reflect / reexamine [3]. In general, the difficulties of students in solving the problem description is that students have difficulty in understanding the problem. According to Junaedi research states that there are still students who take no action against the problem of proof though only at the stage of understanding the problem (understand the problem) [1].

\section{NEWMAN'S ERROR ANALYSIS}

The ability of students in solving a description form needs to be analyzed to find out at the stage where the error occurred. One way to analyze student errors in solving a description form is by NEA procedure (Newman Error Analysis). White states that if one is trying to answer a mathematical problem then that person must be able to go through a number of successive obstacles: Reading, Comprehension, Transformation, Process Skill, and Encoding [6]. In the error reading stage that occurs is the student is not able to read the words and symbols contained in the problem. 
Comprehension phase error that occurs is the student unable to read the problem but failed in getting what is needed so that difficulty solving the problem. Stage Transformation mistakes that occur is the students understand the problem but failed in choosing the right mathematical operations to solve the problem. Process Phase Skill error that occurs is the student is able to choose the right operation in solving the problem but can not run in accordance with the correct procedure. The Encoding Error stage that occurs is that the student finished solving the problem but misinterpreted what was meant.

\section{COGNITIVE STYLE}

One of the student's characteristics is the cognitive style. Putra suggests that cognitive-style relationships and learning achievements show that there is a positive and statistically significant correlation between cognitive style and learning achievement [4]. Warli suggests that cognitive impulsive children are the ones who quickly answer the problem but are less conscientious so the answer is more likely to be the wrong answer, while the child who has a reflexive cognitive style is the child who is slow in answering the problem but thoroughly so the answer to the problem tends right [5]. In this research, there are differences in two aspects: time aspect and uncertainty aspects where time aspect is divided into two that is fast and slow while the uncertainty aspect is divided into two that is accurate / accurate and not accurate / inaccurate. So students are grouped into four categories: fast-accurate, impulsive (fast and inaccurate), reflexive (slow and accurate), and slowinaccurate (slow and inaccurate). Students who are fast in solving the problem but not accurate so the answer tends to be wrong then it is said students are cognitive impulsive style. While the students are slow in solving the problem but accurate so the answer tends to be true then it is said that students are reflexive cognitive style.

The test used in measuring students into which group in cognitive style categorization is MFFT (Matching Familiar Figure Test). This study uses MFFT developed by Warli [5]. The tests given are students shown an image of a standard object and 10 similar object variations but only one object identical to a standard object. Students are asked to choose a variation of an object that is identical to the standard object. Problem MFFT this amounted to 10 questions.

Based on the above description, this study aims to describe students' errors in problem solving using Newman analysis (NEA) to solve the problem of geometry in terms of cognitive style. The cognitive styles used are fast- accurate, impulsive (fast and inaccurate), reflexive (slow and accurate), and slowinaccurate (slow and inaccurate).

\section{RESEARCH METHODS}

The method used in this research is qualitative research. The subjects in this study are 4 students of class of 2016 mathematics education course IKIP Budi Utomo Malang, each consisting of students with different cognitive and gender styles. Data collection techniques in this study using test and interview techniques. This test is used to derive cognitive style data and problem-solving data on geometry the results of student work. Instruments for finding reflective cognitive styles and impulsive cognitive styles using MFFT (matching familiar figure test) developed by Warli [5]. Analysis of the data in this study using a model (Miles, Huberman, \& Saldana, 2014) is data reduction, data presentation, drawing conclusion [2].

\section{RESEARCH RESULT}

Based on the research that has been implemented, then obtained the following results:

Table 1. F-A subject error analysis.
\begin{tabular}{|l|l|l|l|l|l|l|l|l|l|l|l|}
\hline Error & $\mathbf{l}$ & $\mathbf{2}$ & $\mathbf{3}$ & $\mathbf{4}$ & $\mathbf{5}$ & $\mathbf{6}$ & $\mathbf{7}$ & $\mathbf{8}$ & $\mathbf{9}$ & $\begin{array}{c}\boldsymbol{1} \\
\mathbf{0}\end{array}$ & $\begin{array}{c}\text { oun } \\
\mathbf{t}\end{array}$ \\
\hline $\begin{array}{l}\text { Readin } \\
\text { g }\end{array}$ & & & & & & & & & & \\
\hline $\begin{array}{l}\text { Compr } \\
\text { ehensi } \\
\text { on }\end{array}$ & & & & & & & & & & & \\
\hline $\begin{array}{l}\text { Transf } \\
\text { ormati } \\
\text { on }\end{array}$ & & & $\sqrt{ }$ & & & & $\sqrt{ }$ & & $\sqrt{ }$ & & 3 \\
\hline $\begin{array}{l}\text { Proces } \\
\text { s Skill }\end{array}$ & & & & $\sqrt{ }$ & & & & & $\sqrt{ }$ & & 2 \\
\hline $\begin{array}{l}\text { Encodi } \\
\text { ng }\end{array}$ & & $\sqrt{ }$ & & & & & & & & 1 \\
\hline $\begin{array}{l}\text { Amoun } \\
\text { t }\end{array}$ & & & & & & & & & 6 \\
\hline
\end{tabular}

Subjects with fast accurate cognitive style (fast and accurate), which in this study is called the subject of the F-A. The subject solved 6 problems correctly and there were 6 errors of 10 questions. At the transformation stage the subject is wrong in choosing the procedure used to solve the problem. From the interview, subjects stated that it happened because of lack of concentration. At the process skill stage the subject can't complete the procedure correctly 
because it forgets the next step. At the encoding stage the subject is wrong in writing the final result due to lack of care.

Table 2. R subject error analysis.

\begin{tabular}{|c|c|c|c|c|c|c|c|c|c|c|c|}
\hline \multirow[b]{2}{*}{ Error } & \multicolumn{10}{|c|}{ Code Problem } & \multirow{2}{*}{$\begin{array}{c}\text { Am } \\
\text { oun } \\
t\end{array}$} \\
\hline & 1 & 2 & 3 & 4 & 5 & 6 & 7 & 8 & 9 & $\begin{array}{l}1 \\
0\end{array}$ & \\
\hline $\begin{array}{l}\text { Readin } \\
\mathrm{g}\end{array}$ & & & & & & & & & & & \\
\hline $\begin{array}{l}\text { Compr } \\
\text { ehensi } \\
\text { on }\end{array}$ & & $\sqrt{ }$ & & & & & $\sqrt{ }$ & & & $\sqrt{ }$ & 3 \\
\hline $\begin{array}{l}\text { Transf } \\
\text { ormati } \\
\text { on }\end{array}$ & & $\sqrt{ }$ & & & $\sqrt{ }$ & & & $\sqrt{ }$ & & $\sqrt{ }$ & 4 \\
\hline $\begin{array}{l}\text { Proces } \\
\text { s Skill }\end{array}$ & & & & & & & & & & $\sqrt{ }$ & 1 \\
\hline $\begin{array}{l}\text { Encodi } \\
\text { ng }\end{array}$ & & & & & & & & & & & \\
\hline $\begin{array}{l}\text { Amoun } \\
t\end{array}$ & & & & & & & & & & & 8 \\
\hline
\end{tabular}

Subsequently subjects with reflexive cognitive style (slow and accurate), which in this study called the subject of R. Subject R solves 5 problems correctly and there are 8 errors out of 10 questions. In the comprehension phase the subject can't understand the purpose of the proposed problem. Subject is less able to reason. Error in the transformation stage, the subject could not find the proper procedure to solve, caused it does not understand the problem. At the process skill stage the subject could not complete the procedure because it is less forgotten.

Table 3. S-I subject error analysis

\begin{tabular}{|c|c|c|c|c|c|c|c|c|c|c|c|}
\hline \multirow[b]{2}{*}{ Error } & \multicolumn{10}{|c|}{ Code Problem } & \multirow{2}{*}{$\begin{array}{c}\text { Am } \\
\text { oun } \\
t\end{array}$} \\
\hline & 1 & 2 & 3 & 4 & 5 & 6 & 7 & 8 & 9 & $\begin{array}{l}1 \\
0\end{array}$ & \\
\hline $\begin{array}{l}\text { Readin } \\
\mathrm{g}\end{array}$ & & $\sqrt{ }$ & & & & & $\sqrt{ }$ & $\sqrt{ }$ & & $\sqrt{ }$ & 4 \\
\hline $\begin{array}{l}\text { Compr } \\
\text { ehensi } \\
\text { on }\end{array}$ & & $\sqrt{ }$ & & $\sqrt{ }$ & & & $\sqrt{ }$ & $\sqrt{ }$ & & $\sqrt{ }$ & 5 \\
\hline $\begin{array}{l}\text { Transf } \\
\text { ormati } \\
\text { on }\end{array}$ & & $\sqrt{ }$ & & $\sqrt{ }$ & & & & $\sqrt{ }$ & & $\sqrt{ }$ & 4 \\
\hline $\begin{array}{l}\text { Proces } \\
\text { s Skill }\end{array}$ & & & & & & & & & & & \\
\hline $\begin{array}{l}\text { Encodi } \\
\text { ng }\end{array}$ & & & & & & & & & & & \\
\hline Amoun & & & & & & & & & & & 13 \\
\hline
\end{tabular}

Subjects with slow inaccurate (slow and inaccurate) cognitive style or S-I subjects completed 5 questions correctly and 13 errors were made. The error in the reading phase of the subject could not read the image because the subject is confused between waking up the room with a flat wake. In the comprehension phase the subject is unable to understand the problem of the wake-up image of the space due to failure at the reading session. Error in the transformation stage, the subject could not find the proper procedure to solve because it does not understand the problem.

TABLE 4. I SUBJECT ERROR ANALYSIS
\begin{tabular}{|l|l|l|l|l|l|l|l|l|l|l|l|}
\hline Error & $\mathbf{1}$ & $\mathbf{2}$ & $\mathbf{3}$ & $\mathbf{4}$ & $\mathbf{5}$ & $\mathbf{6}$ & $\mathbf{7}$ & $\mathbf{8}$ & $\mathbf{9}$ & $\begin{array}{c}\boldsymbol{1} \\
\mathbf{0}\end{array}$ & $\begin{array}{c}\text { Am } \\
\text { oun } \\
\text { t }\end{array}$ \\
\hline $\begin{array}{l}\text { Readin } \\
\text { g }\end{array}$ & & & & & & & & & & & \\
\hline $\begin{array}{l}\text { Compr } \\
\text { ehensi } \\
\text { on }\end{array}$ & & $\sqrt{ }$ & & & & & & & & & 1 \\
\hline $\begin{array}{l}\text { Transf } \\
\text { ormati } \\
\text { on }\end{array}$ & & $\sqrt{ }$ & & $\sqrt{ }$ & & & $\sqrt{ }$ & & & $\sqrt{ }$ & 4 \\
\hline $\begin{array}{l}\text { Proces } \\
\text { s Skill }\end{array}$ & & & & $\sqrt{ }$ & & & $\sqrt{ }$ & & & $\sqrt{ }$ & 3 \\
\hline $\begin{array}{l}\text { Encodi } \\
\text { ng }\end{array}$ & & & & & & & & & & \\
\hline $\begin{array}{l}\text { Amoun } \\
\text { t }\end{array}$ & & & & & & & & & & & 8 \\
\hline
\end{tabular}

Then subjects with impulsive cognitive style (fast and inaccurate) or subject I solve 6 problems correctly and 8 errors. The error in the comprehension stage is not able to understand the problem of the wake-up image of the space. At the transformation stage, the subject could not be find the proper procedure to complete due to lack of focus on the problem. Furthermore, in the process skill stage, the subject forgot the steps on the procedure use, in that case, it could not solve the problem.

\section{CONCLUSION}

Based on the results of the study that the errors are often done in the stage of transformation and process skills. The error occurs because students do not understand the procedure that will be used to solve the problem, cause the material is not well understood. In addition, the sense of lazy students thought one of the causes of error in solving the problem. Students had a cognitive style that is more likely to be cognitive impulsive and reflexive style of $67.5 \%$.

Researchers provide advice to teachers to instill the concept of prerequisite materials so that students are able to understand the next material. Teachers are also expected to often give practice questions to train students' skills in thinking and counting, and also the lecturers are encouraged to ask students questions about materials that have not been understood or using peer methods so that students who are embarrassed to ask questions directly to the teacher could connected the questions to friends class. 


\section{REFERENCES}

[1] Junaedi, I.. Type of Student Error in Solving Analytical Geometry Problems Based on Newman's Error Analysis (NEA). Type of Student Error. Keyword: Type of Student Error; Newman's Error Analysis, 3(2), 2086-2334 (2012.)

[2] Miles, M. B., Huberman, M. a, \& Saldana, J.. Drawing and Verying Conclusions. Qualitative Data Analysis: A $\begin{array}{lll}\text { Methods } & \text { Sourcebook, 275-322. (2014) }\end{array}$ https://doi.org/January 11, 2016

[3] Polya, G. How to Solve It. The Mathematical Gazette. https://doi.org/10.2307/3609122 (1945)

[4] Putra, A.. Relationship of Cognitive Styles and Verbal Reasoning With Learning Achievement Subjects Anatomy Ii In Students Physical Education Health And Recreation (Faculty Of Sport And Health University Of Education Ganesha). Health Education, 1(1), 92-103. Retrieved

from http://jurnal.pasca.uns.ac.id/index.php/pdpk/article/vie $\mathrm{w} / 232$ (2013)

[5] Warli. (2013). Reflective or Impulsive Cognitive Story Journalist's Creativity in Solving Geometry Problems. Journal of Education and Learning, 20(2), 190-201.

[6] White, A. L.. Numeracy, Literacy and Newman's Error Analysis. Allan Leslie White Journal of Science and Mathematics Education in Southeast Asia, 33(2), 129148 (2010). 